\title{
Evaluation of the impact of market deformations on the competitive environment of the housing investment market
}

\author{
Tatiana Ovsiannikova ${ }^{1, *}$, Inna Salagor ${ }^{1}$, and Irina Yugova $^{1}$ \\ ${ }^{1}$ Tomsk State University of Architecture and Building, 634003, Solyanaya sq., 2, Tomsk, Russia
}

\begin{abstract}
The paper is devoted to the problem of assessing the impact of market deformations on the competitive environment of the housing investment market. The main types of deformations inherent to the market under study and negatively affecting the development of favorable competitive environment have been identified and analyzed. The strongest factor influencing the competitive environment is the imperfect market structure constraining the development of favorable competitive environment and leading to imbalance in the economic interests of developers, housing consumers and public authorities.
\end{abstract}

\section{Introduction}

In the Concept of Social and Economic Development of Russia, the standards of human well-being are established as the main targets - by 2020 the level of incomes and the quality of life of the population of Russia must reach the indicators characteristic for the economies of developed countries, for example, the average level of housing provision is to be 30 square meters per person or about 100 square meters per the average family; the share of the population living in places with an unfavorable environmental situation should decrease to $14 \%$ [1]. Also, according to the socio-economic policy of the Russian Federation, its main priority areas are: creating conditions for the growth of housing market offers, corresponding to the needs of various groups of the population; creation of conditions for increasing affordability of housing for all categories of the Russian citizens; formation of a comfortable living environment; creation of environmentally safe and comfortable environment in the places where people live, work and rest. Thus, we observe the evolution of socio-economic policy both in our country and in many other countries. In our country, in particular, we can see a shift in the priorities of social policy from ensuring minimum guarantees to the population in various areas to the desire of the state to provide the population with a comfortable and environmentally safe living environment.

In our opinion, the development of the housing investment market is the main tool for achieving the state priorities. A balanced supply-demand market is the major parameter that impacts the development of the housing market. The housing investment market is formed in the sphere of housing construction and is, in fact, a part of the construction market.

${ }^{*}$ Corresponding author: expertreal@ mail.ru 
Therefore, subjects of the construction market, the relationship of which does not fit into the classical scheme of relations between market participants: the seller - the buyer, become the economic subjects of the market. The investor, the customer and the contractor, which are often integrated into one organization - a development company that also functions as an investment company and a realtor, i.e. provides search and attraction of investment resources, and sale of real estate, perform the sellers' function on the market. Another feature of the housing investment market is that it includes a residential real estate market, which consists of the two submarkets, namely primary and secondary. At the same time, on the type of a market structure, the primary housing market is oligopolistic because of the limited number of sellers, where three or four large construction companies dominate the market, which determine the dynamics and structure of supply, price and technical policy [2].

These features of the housing investment market complicate the development of a competitive environment, so at this stage, it is important to identify the reasons that affect the development of the competitive market environment. In our opinion, the market deformations are the main causes of imperfection of the competitive environment.

\section{Theory and methodology of research of a competitive environment under conditions of market deformations}

The term of "competitive environment" was theoretically formed largely under the influence of the Walter Eucken's theory of "a competitive order". According to his definition, a competitive environment is "a set of constitutive and regulatory principles that signify legislatively fixed norms and rules of management, changing under the impact of the results of implementation of the assigned goals" [3]. At the present stage of the development of economic science, the competitive environment is understood as the economic conditions in which the producers of goods and services are fighting for the consumer, counterparties and position on the market. The competitive environment determines the nature of the relationship of economic entities regarding the establishment of prices and volumes of sales of goods on the market, the degree of their competition for the share of market. The state of the competitive environment largely determines the prospects for the growth of the commodity market. According to E. Mason and J. Baine, the most important element of the competitive environment is the market structure, which influences the behavior of market actors and, ultimately, the effectiveness of the market $[4,5]$. Therefore, a structural approach is most often used in the research of scientists in assessing the competitive environment.

In the economic literature, there are various definitions and classifications of disproportions, but the mechanism of occurrence of these or those disproportions is understood as the unbalanced distribution of various resources between different commodity markets and industries. In general, disproportions in the economy are interpreted as the imbalance in the development of individual industries, interrelated phases of production, generating a violation of the norms of the reproduction process. There are partial disproportions that are of local and short-term nature, and general ones associated with the shock for the entire economy [6].

The main type of disproportions inherent to the housing investment market, and impeding the development of favorable competitive environment are structural disproportions. Some other types of imbalances have been identified, and their manifestation is described in the Table 1 [7]. In the opinion of N.I. Usik, in the Russian economy, after privatization and in the conditions of impossibility of capital accumulation due to high inflation and instability, holding and group structures were the only way out, which allowed substantially equalizing the flow of cash receipts [8], but the level of competition significantly decreased. Structural imbalances manifest themselves in an imperfect type of market competition. In the conditions of oligopoly, organizations tend to come to the agreement (cartel) about prices, division of 
the market, and joint use of channels for the sale of products. As a result, the aggregate of oligopolistic enterprises acts as a monopoly, but formally they are not subject to antimonopoly sanctions of the state. To confirm the oligopolistic structure of housing investment markets in most regions of our country, one can analyze the reports on the implementation of the program "Housing for the Russian family" [9]. So, for example, in 2018 just one developer was involved in the program in the Moscow region, one developer in the Leningrad region, and the number of developers in other regions is represented in the Figure 1.

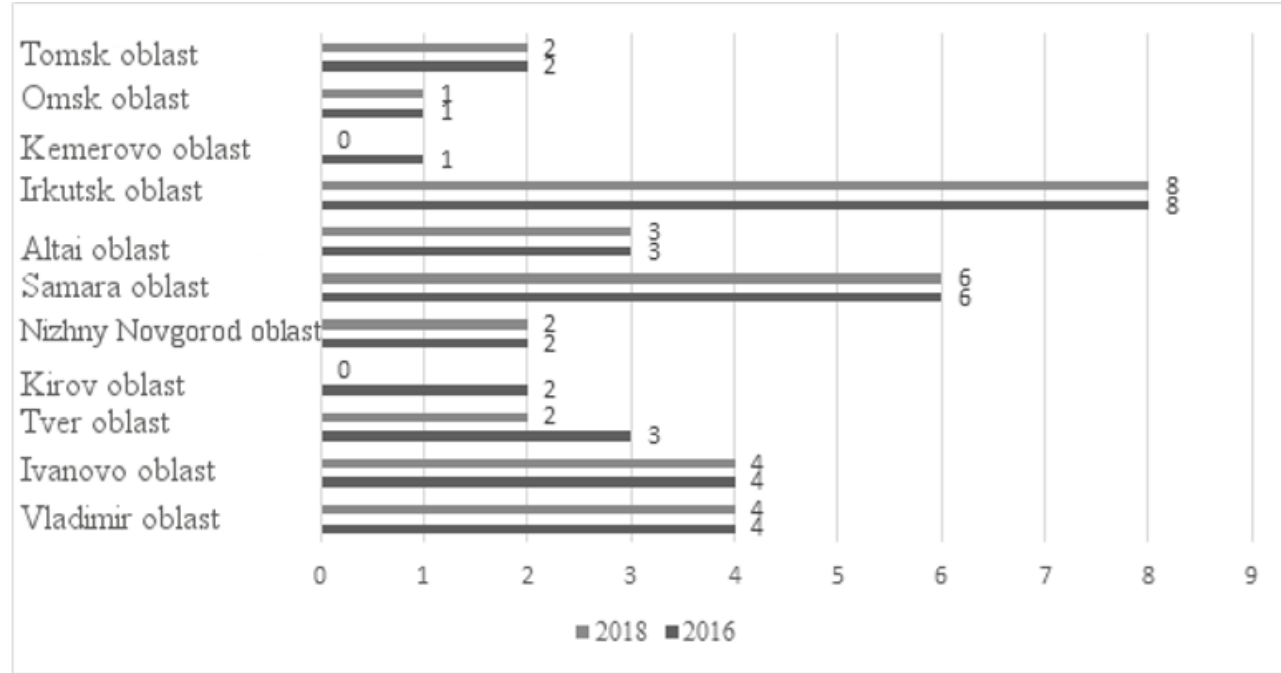

Fig. 1. Dynamics of the number of developers [Calculated by the authors].

Table 1. Types of deformations on the housing investment market and the forms of their manifestation.

\begin{tabular}{|l|l|}
\hline Types of deformations & Forms of manifestation \\
\hline 1.Structural & Violation of the market structure, strengthening of the oligopoly. \\
\hline 2.Reproductive & $\begin{array}{l}\text { Primarily, investments are invested in new construction, at the } \\
\text { expense of renovating the existing housing stock. }\end{array}$ \\
\hline 3.Institutional & $\begin{array}{l}\text { The state accepts laws that severely restrict the activities of } \\
\text { developers, trying to protect housing consumers. }\end{array}$ \\
\hline 4. Pricing & $\begin{array}{l}\text { The level of prices on the primary housing market does not allow } \\
\text { the population to accumulate amounts sufficient to improve housing } \\
\text { conditions, even for people with high incomes. }\end{array}$ \\
\hline 5.Regional & $\begin{array}{l}\text { Uneven distribution of housing investment across Russia. As the } \\
\text { regions move away from the federal center and the territories close } \\
\text { to it, their socio-economic indicators deteriorate. }\end{array}$ \\
\hline 6.Macro-economic & $\begin{array}{l}\text { Inflationary expectations transform the pent-up demand for housing } \\
\text { into real demand, while deflationary ones freeze the demand. }\end{array}$ \\
\hline
\end{tabular}

The deformation of the commodity market as the destruction of the existing production relations arises from global or national economic crises and is manifested in the disproportions and imbalance of the main market parameters. The less perfect is the economic system, the more profound deformations it is exposed to. The housing investment market cannot be called a sufficiently mature market system; it, like the construction sphere in general, has a low sensitivity threshold to crises: on the eve of crises, the housing investment market reacts more quickly, and in the post-crisis conditions it recovers more 
slowly than other commodity markets. But if in the initial phase of the crisis the housing investment market shows rapid growth, then in the post-crisis phase there is obviously a lagging recovery. This can be seen from the data in the table referring to the comparison of the main indicators of the economic dynamics of Russia (gross domestic product, GDP) and the housing market $[10,11]$.

Table 2. The main indicators of the economic dynamics of Russia (gross domestic product) and the housing market.

\begin{tabular}{|l|l|l|l|l|}
\hline Indicators & 2014 & 2015 & 2016 & 2017 \\
\hline GDP, trillion rubles & 79.20 & 83.20 & 86.00 & 92.00 \\
\hline GDP, rates of growth & 100.7 & 97.2 & 99.8 & 101.5 \\
\hline Housing commissioning, mil m2 & 84.20 & 85.30 & 80.20 & 78.60 \\
\hline $\begin{array}{l}\text { Housing commissioning, rates of } \\
\text { growth }\end{array}$ & 118.2 & 101.4 & 94.0 & 97.09 \\
\hline
\end{tabular}

\section{Analysis of market deformations and their impact on the competitive environment}

To date, equity contracts or other investment contracts are the main financial mechanism for attracting housing investment. This mechanism not only allows developers to get cheap money, but also credits them without interest, since the bulk of contracts are signed at the initial stage of construction. The first signs of economic instability alarm potential buyers on the residential real estate market, and, fearing to replenish the cohort of "deceived coinvestors," they lose potential interest in new buildings. As a result, demand is falling down and supply becomes excessive, which contributes to lower prices and a drop in the primary housing market. Also, this deformation factor is manifested in the fact that trying to protect the buyer (shareholder) in the market, the state enacts laws that severely restrict the activities of developers, setting high administrative barriers to entry to the market. The deformation is that the shareholder is in a weak position compared with the customer, and the customer, in turn, is limited by law. Thus, again there is an imbalance of supply and demand, and it leads to a decrease in supply on the market, the buyer's lack of choice and price growth, respectively.

Price deformations are the consequence of imperfection of the market structure. They are revealed in the fact that the prevailing level of prices in the primary housing market, especially in large cities, does not allow the population to accumulate amounts sufficient to improve housing conditions, even for people with high incomes. At the same time, if we talk about the normal ratio between the price of one square meter of housing and the monetary incomes of the population, then in all developed countries the cost per square meter of "the people's housing" or "the economy class" housing does not exceed the average monthly salary. The analysis of comparison of the price of one square meter of housing with per capita income of the population has shown that the average cost of a square meter of housing exceeds the average income of the population almost twice. This is provided that there are no any household expenses (Figure 1).

The majority of scientists, studying competitive environment on the commodity market, rely on the evaluation of various indicators of market concentration, of which the Herfindahl-Hirschman Index is the most widely known. The evaluation of the level of competition carried out by the authors on the basis of calculation of concentration coefficients on the Tomsk housing investment market showed that in recent years the level of market concentration has increased that led to a significant deterioration of the competitive environment (Figure 2) [15]. 


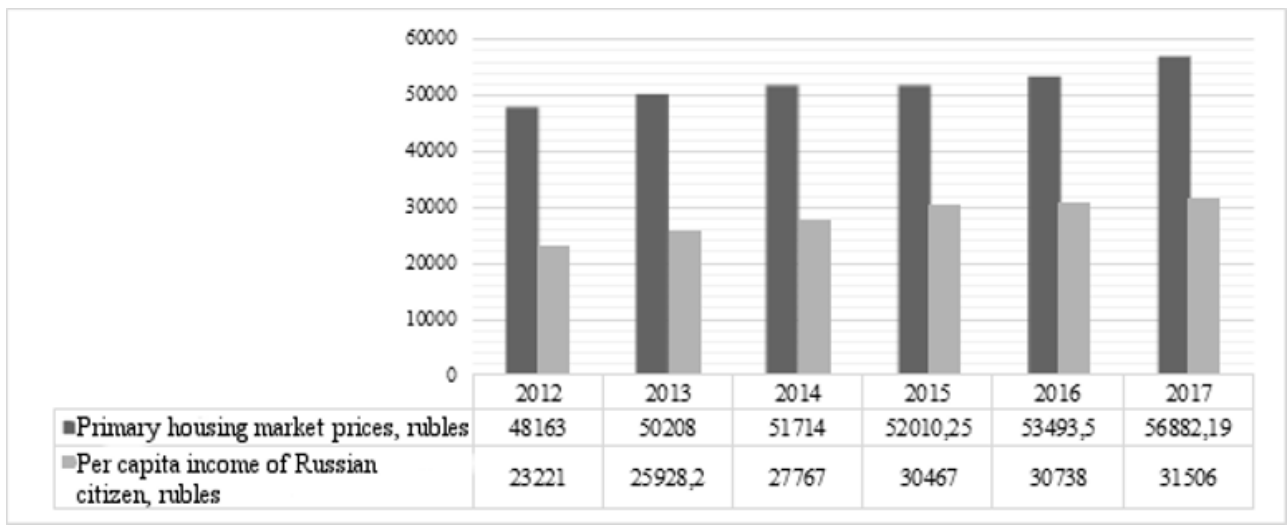

Fig. 2. Dynamics of prices in the primary housing market (PHM) in Russia and per capita income of the population [15].

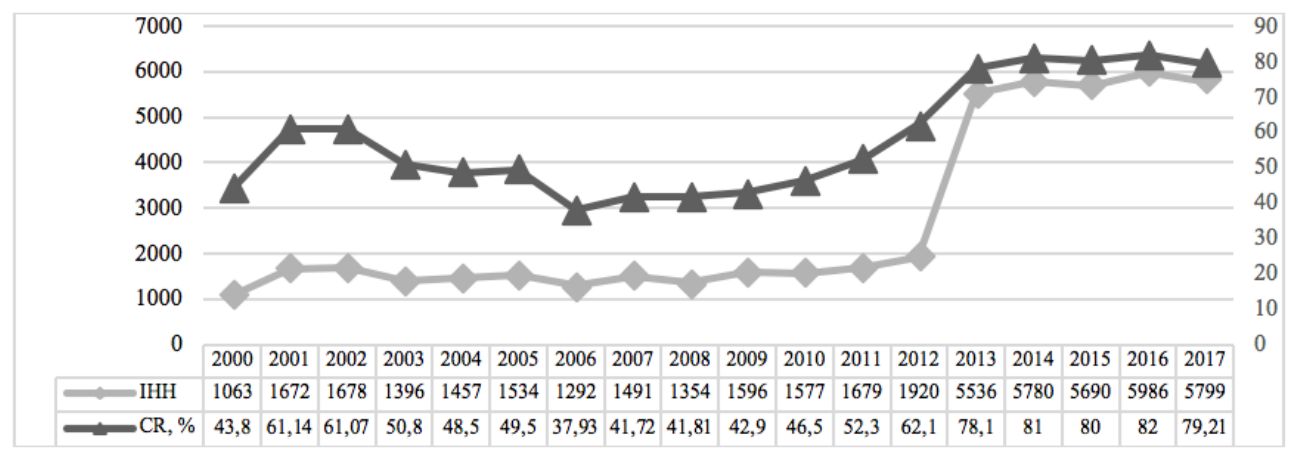

Fig. 3. Dynamics of concentration indicators of the primary housing market on the example of the Tomsk region [Calculated by the authors].

Meanwhile, it is needed to take into account that not only the market power of companies on the commodity market determines the competitive environment, but also the capabilities of the company to impact the related markets and to be the subject of other markets. This is the most important factor for the analysis of markets of the resource-intensive goods, in which the cost of resources constitute a significant part of their final value. Therefore, when assessing the competitive environment, special attention should be paid to verticallyintegrated companies - the market leaders, market power of which extends to related commodity product markets.

\section{Conclusion}

Thus, it can be concluded that, of the revealed market deformations inherent to the market under study, the major influence on the competitive environment exert the following: an incomprehensive market structure constraining the development of a favorable competitive environment and an imbalance in the economic interests of developers, housing consumers and government agencies, since developers are not interested in minimizing costs for the construction and operation of housing, their economic interest ends with the moment of the purchase transaction, and the state establishes high administrative barriers to entry to the market. As a result, only large companies operate on the market, which unite and act as a pure monopoly. Undeveloped competitive environment adversely affects all market participants. The main task of the state, in this situation, is to ensure conditions for stable 
and sustainable development and creation of a favorable competitive and institutional environment. To do this, it is necessary to monitor the market situation continuously, to assess supply and demand, identify market disparities and respond to them in a timely manner, and also assess market structure of the housing investment market.

\section{References:}

1. Government of Russia, The concept of long-term socio-economic development of the Russian Federation for the period until 2020 (http://www.consultant.ru/document/cons_doc_LAW_82134/28c7f9e359e8af09d7244 d8033c66928fa27e527, 2017)

2. T. Yu. Ovsyannikova, I. V. Yugova, Tomsk State University Journal of Economics, 4, 122-137 (2016)

3. L. I. Tsedelina, K. Herrmann-Pillata V. Oyken, Basic principles of economic policy (Progress, Moscow, 1995)

4. E. Mason, Journal of Farm Economics, 40(2), 506-508 (1958)

5. J. Bain, Barriers to new competition (Harvard Univ. Press, Cambridge, 1956)

6. Great encyclopedic dictionary (https://dic.academic.ru/contents.nsf/enc3p/)

7. Federal State Statistics Service, Investments in fixed assets in the Russian Federation by types of fixed assets (http://www.gks.ru/free_doc/new_site/business/invest/Invvf.xls, 2017)

8. N. I. Usik, Theoretical Economics, 4, 33-42 (2012)

9. Report on the implementation of the program "Housing for the Russian family" (http://program-free.rf/statistics, 2018)

10. Rosstat, Russian statistical yearbook (Moscow, 2017)

11. Rosstat, GDP (the second estimate in 2017) - operational information of Rosstat (http://www.gks.ru/wps/wcm/connect/rosstat_main/rosstat/en/rates/46880c804a41fb5 3bdcebf78e6889fb6)

12. Y. V. Ragulina, A. V. Bogoviz, A. N. Alekseev, Advances in Intelligent Systems and Computing, 622, 568-573 (2018)

13. Federal Service of State Statistics, Average prices in the housing market (https://www.fedstat.ru/indicator/31452)

14. A. V. Bogoviz, S. V. Lobova, A. N. Alekseev, I. A. Koryagina, T. V. Aleksashina, Advances in Intelligent Systems and Computing, 622, 609-616 (2018)

15. I. V. Yugova, Economic Revival of Russia, 3(41), 111-115 (2014) 